\title{
An Overview of Credit Report/Credit Score Models and a Proposal for Vietnam
}

\author{
Le Duc Thinh* \\ VNU International School, Building G7-G8, 144 Xuan Thuy, Cau Giay, Hanoi, Vietnam \\ Received 04 April 2017 \\ Revised 10 June 2017; Accepted 28 June 2017
}

\begin{abstract}
Having a national credit database system would help financial institutions (FIs) reduce credit risk and reduce non-recovered bad debts. The government will feel at ease when FIs and the people are protected from bad debts in a sustainably developing and transparent market. On the other hand, borrowers will also receive benefit. Those who have good credit history will be provided with a more favorable interest rate and less requirements, or even without collateral.

In 2014 the Vietnam National Assembly passed the Citizen Identity Law, which requires the government to issue a unique lifetime personal identification number for each citizen (starting 2016). This will play a crucial role in building a national credit database system. In this article we will give an overview of credit report and credit score models, mainly in the United States. Based on that, we draft a detailed proposal for a national credit database system which can be implemented in Vietnam.
\end{abstract}

Keywords: Credit history, Credit report, Credit score, FICO scores.

\section{Introduction}

Vietnam is a nation with a population of about 90 million people and 600,000 small and medium enterprises (SMEs). According to the data from the Vietnam Chamber of Commerce and Industry (VCCI), only $30 \%$ of SMEs have managed to secure bank loans [1]. Similarly, only a small percentage of population can borrow from banks. This is a very low rate compared to other countries in the region (such as Thailand and Malaysia). One of many reasons why banks and financial institutions (FIs) in general have not been able to expand

\footnotetext{
* Tel.: 84-2435579083.

Email: thinhld@isvnu.vn

https://doi.org/10.25073/2588-1116/vnupam.4100
}

their customer base is that they cannot collect enough reliable information to make credit granting decision as well as managing credit risk among this large number of customers.

Having a national credit database would help FIs reduce credit risk and reduce nonrecovered bad debts. The government will feel at ease when FIs and the people are protected from bad debts in a sustainably developing and transparent market. On the other hand, borrowers will also receive benefit. Those who have good credit history will be provided with a more favorable interest rate with less requirements, or even without collateral.

Moreover although there are many factors that affect how a nation responses to the economic crisis but if a country does not have 
credit bureau(s) or a credit report system (such as Greece), it would face more difficulties than those with established credit bureau(s).

Currently, credit rating activities have shown the role of limiting credit risk internally in Vietnam. However, they still face many difficulties and obstacles in reality. Vietnam's financial markets are immature and the information's reliability is low, while credit report and credit score models require a large number of figures or individual's information to analyze the credit rating. It means that Vietnam's credit database systems are poor and underdeveloped and even personal credit rating almost does not exist. Therefore, the study of how to improve the quality of credit rating is quite necessary, especially the study on credit report and credit score.

In 2014 the Vietnam National Assembly passed the Citizen Identity Law, which requires the government to issue a unique lifetime personal identification number for each citizen (starting 2016) [2]. This will play a crucial role in building a national credit database system, like in many developed countries.

In this article we will give an overview of credit report and credit score models, mainly in the United States (US). Based on that, we draft a detailed proposal for a national credit database system which can be implemented in Vietnam.

\section{Credit report}

\subsection{Personal credit report}

A credit report is a statement that has information about an individual's credit activity and current credit situation such as loan paying history and the status of credit accounts.

Credit reporting companies, also known as credit bureaus or consumer reporting agencies, collect and store financial data about an individual that is submitted to them by creditors, such as lenders, credit card companies, and other financial companies.
Creditors are not required to report to every credit reporting company. In the US, there are three major consumer reporting companies: Equifax, Experian and TransUnion.

Lenders use these reports to help them decide if they will loan a person money, what interest rates they will offer that person. Lenders also use a person's credit report to determine whether he/she continues to meet the terms of an existing credit account. Other businesses might use credit reports to determine whether to offer a person insurance; rent a house or apartment to a person; provide a person with cable $\mathrm{TV}$, internet, utility, or cell phone service. If a person agrees to let an employer look at his/her credit report, it may also be used to make employment decisions about that person.

In the US, credit reports often contain the following information [3]:

\section{Personal information:}

Name and any name a person may have used in the past in connection with a credit account, including nicknames

- Social Security number

- Birth date

- Current and former addresses

- Phone numbers

We note that the Social Security number is the key to establish an individual's credit history.

\section{Credit accounts:}

- Current and historical credit accounts, including the type of account (mortgage, installment, revolving, etc.)

- The credit limit or amount

- Account balance

- Account payment history

- The date the account was opened and closed

- The name of the creditor

Collection items

Public records: 
Liens

Foreclosures

Bankruptcies

Civil suits and judgments

A credit report may include information on overdue child support provided by a state or local child support agency or verified by any local, state, or federal government agency.

Inquiries:

Companies that have accessed a person's credit report.

The following picture is the first page of a sample credit report from Experian [4]:

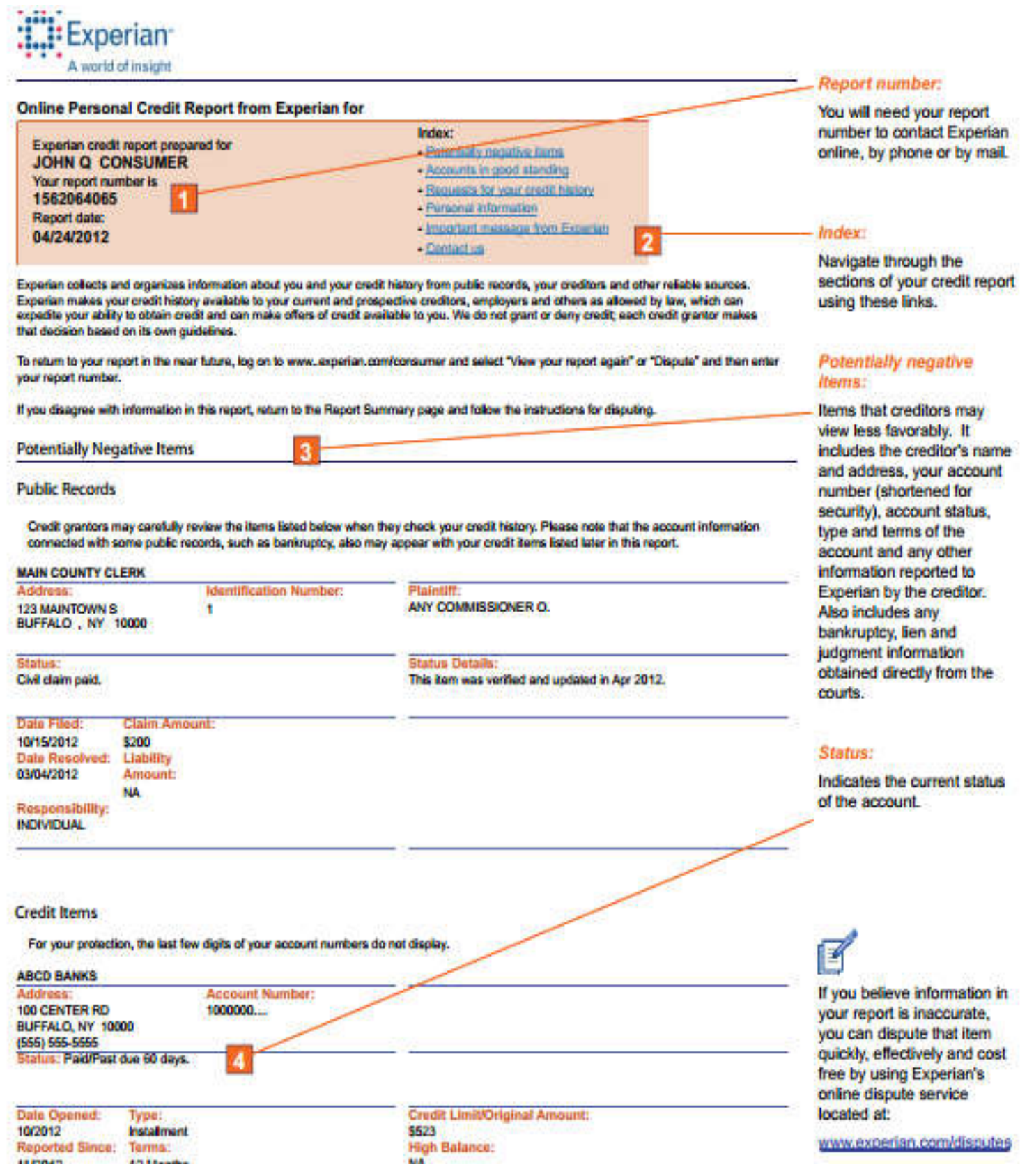




\subsection{Business credit report}

A business credit report is a statement that has information about a business's credit activity and current credit situation. A business credit report often contains the following information [5]:

- Company Profile: key firmographic information such as company name, address, and phone numbers.

- Credit Summary: synopsis of the business' credit accounts with banks, suppliers and service providers.

- Public Records: Secretary of State business registration, judgments, liens, or bankruptcies reported for the business.

- Payment Trend and Payment Index: a 12month payment trend and comparison to the industry norm.

- Additional Company Information: alternate business names, owner and guarantor names, and business and credit grantor comments.

- Business Risk Scores: can help the company identify potential risk of late payments and business failure.

- Business Credit Risk Score: can predict the likelihood of a business incurring a 90 days severe delinquency or charge-off over the next 12 months

Business Failure Score: can predict the likelihood of a business failing through either formal or informal bankruptcy over the next 12 months.

We note that in US, lenders will require personal guarantee for loans to SMEs, so personal credit reports play the main role in the lending industry.

\section{Credit score}

\subsection{General information}

A credit score predicts how likely a person is to pay back a loan on time. A scoring model uses information from a person's credit report to create a credit score for that person.

Companies use a mathematical formula called a scoring model - to create credit score from the information in a person's credit report.

Some factors that make up a typical credit score include:

- The bill-paying history

- The current unpaid debt

- The number and type of loan accounts the individual has

- How long the individual has had loan accounts open

- How much of available credit the individual is using

- New applications for credit

- Whether the individual has had a debt sent to collection, a foreclosure, or a bankruptcy, and how long ago.

Companies use credit scores to make decisions such as whether to offer a person a mortgage, credit card, auto loan, or other credit product. They are also used to determine the interest rate that person receives on a loan or credit card, and the credit limit.

Keep in mind there is no "one" credit score. It is important to know that each person does not have just "one" credit score and there are many credit scores available to a person as well as to lenders. Any credit score depends on the data used to calculate it, and may differ depending on the scoring model, the source of credit history, the type of loan product, and even the day when it was calculated.

Usually a higher score makes it easier to qualify for a loan and may result in a better interest rate.

\subsection{FICO scores}

A classic FICO score is a three digit number between 300 and 850 , industry specific scores have differing ranges. It was developed by the Fair Isaac Corporation (now under the name "FICO") in 1989 to help creditors quickly 
and more effectively judge an individual's credit risk. It is currently used by more than $90 \%$ of all lenders in the US and a total of over 100 billion have been sold worldwide to individuals and lenders. It is increasingly being used outside of the financial arena by insurance companies, employers, landlords and even the armed forces to help them evaluate potential risks.

\subsubsection{How is a FICO score calculated?}

As mentioned above, a FICO score is calculated by looking at the data found in an individual's credit report. Each individual actually has three credit reports, one from each of the credit bureaus (TransUnion, Equifax \& Experian) meaning everybody actually has multiple FICO scores (in fact there are 49 variations on FICO scores). The data found in these credit reports is broken down into five categories: payment history, credit utilization, length of credit history, types of credit used and recent searches for credit.

\section{a) Payment history: 35\%}

Payment history is the most important factor in determining FICO scores and accounts for $\sim 35 \%$ of the total. Lenders want any money they lend to be repaid (with fees and interest of course) which is why such emphasis is put on the history of repayment.

If a payment is made late or not at all (referred to as a delinquency) the FICO algorithm will take into account the following in determining how much of a negative impact it will have:

- How late the payment was made

- How much was owed

- How recently it happened

- How many other late or missing payments there are

A track record of little to no late payments will lead to a higher FICO score while a history of late payments will result in a lower score.

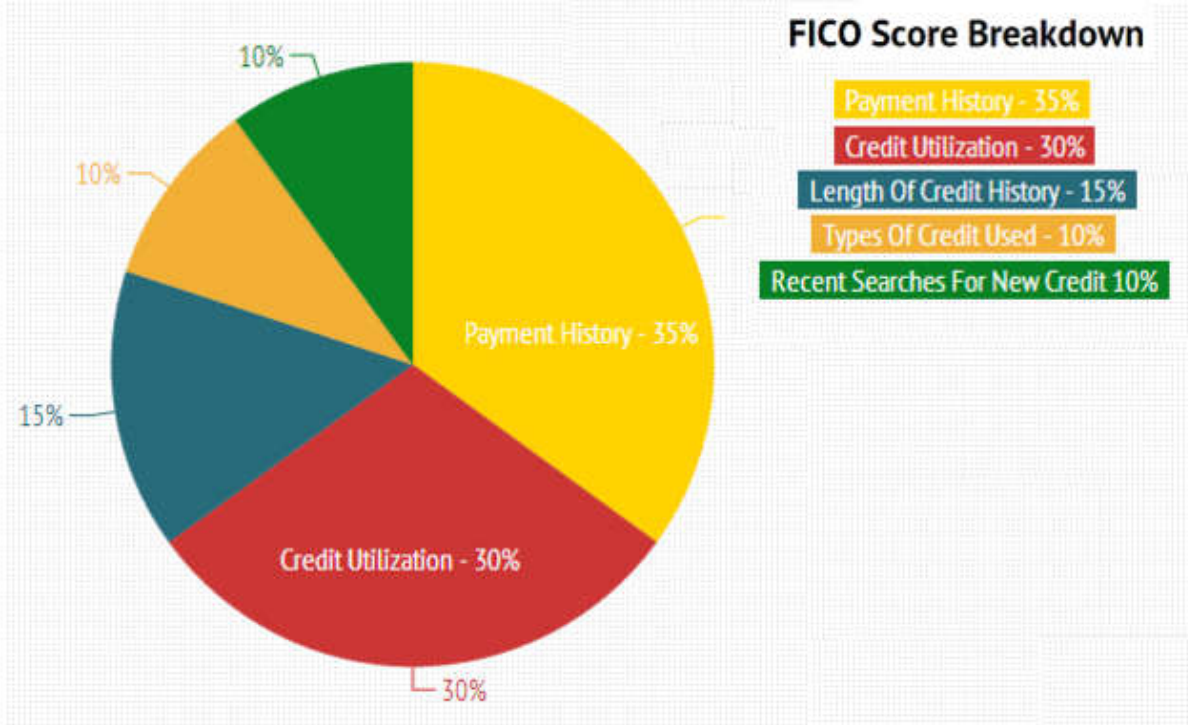

\section{b) Credit utilization: $30 \%$}

Credit utilization ratio (amount of money borrowed divided by the total amount of credit available to them) accounts for $30 \%$ of a FICO score. The lower credit utilization, the better. A low credit utilization shows the individual only 
uses a small amount of the credit that has been loaned to that individual. Revolving credit (e.g credit cards) counts towards the majority of the credit utilization ratio $(>95 \%)$, while installment loans (mortgages or auto loans) count towards a very small minority $(<5 \%)$.

The FICO scoring model looks at the credit utilization in two parts. First, it scores the credit utilization for each of credit cards separately. Then, it calculates the overall credit utilization, that is, the total of all credit card balances compared to the total credit limits. A high credit utilization in either category can hurt credit score.

\section{c) Length of credit history: $15 \%$}

Credit history length makes up $15 \%$ of a total FICO score, but it is not only the oldest account that is looked at. FICO takes into account the following factors:

- Age of oldest account

- Age of newest account

- Average age of all accounts

How long since specific accounts have been used

The older the history of credit, the better the FICO score is likely to be. This is because it shows lenders that the borrower has displayed the same behavior over a long period of time.

\section{d) Recent searches for new credit: $10 \%$}

Recent searches for new credit make up $10 \%$ of the FICO score algorithm. Having a lot of searches for new credit will negatively affect a FICO score because this behavior is considered risky by lenders. It's weighted more heavily when not much other credit information is available.

\section{Soft inquiries versus Hard inquiries}

When applying for new loans it is important to know what does and does not count as a search for credit. There are two types of credit inquiries, soft (does not affect credit scores) and hard (does affect credit scores). These are also sometimes known as soft pulls and hard pulls.
Both hard and soft inquiries allow a third party such as a creditor to view a person's credit report, but only hard inquiries will negatively affect that person's FICO score. A hard credit inquiry will stay on credit report for a period of two years and stop affecting FICO after a period of one year.

A hard credit inquiry is when a credit report is pulled to help aid in a lending decision. For example, when a consumer applies for a mortgage, the mortgage company will use a hard inquiry to access that consumer's credit report. These hard inquiries stay on credit reports for up to two years and usually cause the consumer's credit score to drop by a few points, as time progresses this penalty is slowly reduced. After two years the hard inquiry drops off an individual's credit reports and no longer affects their credit score. An individual must authorize a hard inquiry is performed (simply applying for a credit card or other loan is considered authorization).

A soft credit inquiry is when a credit report is pulled but is not used in a lending decision. Often an individual will not be aware that a soft credit inquiry has even been performed. An example of a soft inquiry is when a credit card issuer pre-approves an individual for a credit card. Individual's accessing their credit scores also counts as a soft credit inquiry and does not affect their credit score.

\section{e) Types of credit used: $10 \%$}

Types of credit used accounts for $10 \%$ of an individuals FICO score. There are two main types of credit: revolving and installment. Lenders look for people for multiple types of credit. When industry specific scores are used (e.g bankcard or auto) the scoring model will give more weighting to the type of credit most similar to that specific scoring model (e.g bankcard models will give more weight to revolving credit whereas auto models give more to installment credit).

\section{Revolving credit}

A revolving credit account has a predetermined credit limit that the owner can 
borrow up to. Interest is only paid on the amount borrowed and not the credit limit. Once money is paid back, it can be re-borrowed (e.g Tony has a credit limit of $\$ 100$, he borrows $\$ 50$ and then pays it back with interest. He can now borrow up to a maximum of $\$ 100$ again).

The most common type of revolving credit is a credit card. Other types include store cards and a line of credit for a business.

\section{Installment Credit}

Installment credit accounts have a fixed number of payments that must be made. Interest is paid on the whole amount owing, regardless of how much of the credit he borrower is actually using. Once money is paid back it cannot be re borrowed without refinancing. It's usually used for a specific large purchase.

The most common type of installment credit is a mortgage or auto loan.

\subsubsection{Types of FICO scores}

In total there are 49 different FICO scoring algorithms that are made available to creditors to assist in their lending decisions, 9 of these are or were accessible to individuals. The reason there are so many different FICO scores is because there are a number of industry specific scores (34 in total) that are rarely used and don't differentiate much from the 9 classic/generic scores. There are also 6 NextGen scores which are also rarely used by lenders and are not accessible to individuals.

\section{Classic / Generic Scores}

There has been four major revisions to the FICO score in 1995, 1998, 2004 and 2008. For every revision there is one classic or generic score for each of the three bureaus. Because the 1995 model is no longer accessible to consumers and no longer used by any creditors we no longer count these as one of the 49 FICO scores.

This leaves the revisions in 1998, 2004 and 2008 , because there are a total of three credit bureaus and they all have their own credit data this gives us the 9 credit classic credit scores that are/were available to consumers.

\section{Industry Specific Scores}

The main difference between industry specific scores and classic scores is the range that these scores fall into. An industry specific score falls between $150-950$ whereas a classic score falls between 300-850.

In 1998 \& 2004 all three of the bureaus also introduced four different industry specific algorithms (Installment loan, Bankcard, Auto \& Personal Finance) this is a total 24 industry specific FICO scores which are only available to creditors for the '98 and '04 models.

The 2008 revision saw the removal of the Installment Loan \& Personal Finance FICO scores by TransUnion \& Experian and the additional of the Mortgage FICO score by all three bureaus, this accounts for the other 10 industry specific scores.

\section{NextGen RISK Scores}

Next generation scores (commonly known as NextGen Risk scores) also follow a range of 150-950. There has been two revisions to NextGen (first in 2001, the second is unknown) and while FICO claims that these scores can help the number of approved loans while decreasing the number of delinquencies it is rarely used by lenders and is not available to individuals. There is a total of six NextGen scoring models (two for each of the credit bureaus).

\subsection{FICO score range}

\begin{tabular}{ll}
\hline FICO Score & Grade \\
\hline $720-850$ & Excellent \\
$700-719$ & Very Good \\
$675-699$ & Good \\
$620-674$ & Fair \\
$560-619$ & Bad \\
$500-619$ & Very Bad \\
$300-499$ & Poor \\
\hline
\end{tabular}


A FICO score ranges between 300 and 850 , with 850 being the best score a consumer can achieve and 300 being the worst. FICO score categories are further broken down grades such as "excellent" (the best grade achievable) and "poor" (the worst grade given).

It may seem unusual to group scores into these ranges, but it makes sense when it is put into practice. One of the things lenders use these scores for is determining what interest rate will be offered, it would get extremely complex and difficult to manage/maintain if everybody was offered a different rate based on their individual score so instead lenders use these grades (or ranges) to work out an individuals interest rate.

\begin{tabular}{lll}
\hline FICO Score & Grade & Typical Mortgage Rates \\
\hline $720-850$ & Excellent & $\mathrm{A}$ \\
$700-719$ & Very Good & $\mathrm{A}+0.13 \%$ \\
$675-699$ & Good & $\mathrm{A}+0.65 \%$ \\
$620-674$ & Fair & $\mathrm{A}+1.80 \%$ \\
$560-619$ & Bad & $\mathrm{A}+4.30 \%$ \\
$500-619$ & Very Bad & $\mathrm{A}+5 \%$ \\
\hline
\end{tabular}

As shown by table above, as a consumer's score decreases the interest rate they are offered increases exponentially. Scores below 500 are not graded or given a typical mortgage rate as borrowers with these scores are almost never approved for loans, unless they are geared to people with bad credit in which case a FICO score is generally not taken into account.

(Source: $[6,7]$ )

\section{What has been done in Vietnam so far?}

\subsection{The national credit information centre of Vietnam}

The National Credit Information Centre of Vietnam (CICB) [8] is the public credit registry in Vietnam, formed by the State Bank of Vietnam (SBV) initially in 1992 as "Credit Risk Prevention Division" under the management of Credit Department. In 1999 it was reorganized as "Credit Information Centre" - a public credit registry of SBV in accordance with Decision 68/1999/QD-NHNN dated 27/2/1999 issued by the Governor of SBV. In 2014 it was restructured and renamed as "National Credit Information Centre of Vietnam" in accordance with Decision 324/QD-NHNN dated 26/2/2014 by the Governor of SBV.

The CICB has functions of: (i) credit registry; (ii) collecting, processing, storing, and analyzing credit information; (iii) rating and scoring, with the aims of supporting SBV's supervision functions and providing credit information services pursuant to SBV's regulation and Vietnamese law.

CICB's range of products and services is regarded as a reliable source of information which greatly contributes toward SBV's management, safe and effective business of credit institutions and enterprises.

\subsection{Vietnam credit information joint stock company}

Vietnam Credit Information Joint Stock Company (PCB) [9] was official established in July 2010 under the Decree 10/2010/TT-NHNN by the Prime Minister and the Circular $16 / 2010$ /TT-NHNN by SBV, aiming to build and operate a first world class private credit bureau in Vietnam.

PCB was jointly founded by 11 leading banks in Vietnam, collecting both positive and the negative information from the financial institutions (FIs) and non-financial institutions about the ability to pay debts of individual, company or organizations. The data collected by PCB is shared equally among shareholders. Organizations that provide data to $\mathrm{PCB}$ can obtain PCB's credit reports while those that do not provide information cannot. 


\section{Our proposal}

Even though there are $\mathrm{CICB}$ and $\mathrm{PCB}$, personal credit rating in Vietnam is still limited. We think the reason is that Vietnam still does not have a complete national credit database system, which has a unique credit profile for every citizen. In 2014 the Vietnam National Assembly passed the Citizen Identity Law, which requires the government to issue a unique lifetime personal identification number for each citizen. The new 12-digit ID card contains basic personal details regarding the background and biometric information of a Vietnamese national and has been issued by the Police General Department of Administration and Social Security (PC64) since the beginning of 2016

This new ID number provides the key to build a credit profile for every citizen, similar to the Social Security number in the US. Here is our proposal in details:

\subsection{National credit database system}

There should be a unique national credit database system based on the new 12-digit personal identification numbers. This system should be built jointly by PC64 and CICB. The system must be completely digital and accessible online.

Information collecting: the ID card already contains the following personal information: full name (including any nicknames), date of birth, gender, ethnic grouping, place of birth, permanent address. The national credit database system should collect the following additional information from financial institutions (FIs) and other sources:

- Current and former addresses

- Phone numbers

- Credit accounts: Current and historical credit accounts, including the type of account (credit card, mortgage, car loan, etc.); The credit limit; Account balance; Account payment history; The date the account was opened and closed; The name of the creditor

- Collection items

- Public records: Liens; Foreclosures; Bankruptcies; Civil suits and judgments; Overdue child support

-Inquiries: Companies that have accessed the individual's credit report within the last 2 years.

Reporting policy: All FIs must report digitally any change in the list of information above of their borrowers within 30 days to the national credit database system.

Accessing policy: the national credit database system must be completely accessible online. All citizens have the right to access their own credit profiles. All FIs have the right to access their existing borrowers' credit profiles automatically (soft pull). When an individual seeks for new credit, they must authorize lenders to obtain his/her credit history (hard pull). Similarly, other businesses (employers, utility companies, etc) are allowed to access a person's credit profile when they are authorized by that person. Private credit bureaus (such as Vietnam Credit Information Joint Stock Company) are also allowed to access the national credit database system.

Fee policy: to build and maintain the national credit database system, the government must collect fee from FIs and other businesses automatically every time they access the system. For individuals, each person should be allowed to access his/her own credit profile once per year, after that the person must pay a fee.

Bad debt: bad debts can be defined as loans showing on the national credit database system which have been overdue for more than 90 days.

\subsection{Credit score}

The government should allow private credit bureaus to provide credit scores to financial institutions and consumers. However every 
credit score model must be based on the information obtained from the national credit database system.

Obviously FICO score models introduced in part III are very good ones to use. That is, a credit score should be calculated based on five information components obtained from the national credit database system: payment history, credit utilization, length of credit history, types of credit used and recent searches for credit.

Each financial institution, especially commercial bank, can also build its own credit score model for credit rating based on the target customers. Again, every credit score model must be based on the information obtained from the national credit database system. Lending to small and medium enterprises (SMEs) should be based on personal guarantee (owners of businesses), that means it is based on personal credit rating. This will help SMEs have access to credit from financial institution more easily.

\section{Conclusion}

Having a good national credit database system is very crucial to any country since it can help the retail banking and consumer credit market become prosperous. Financial institutions' portfolio will be more secured when they have the most accurate and timely information provided by the national credit database system. The government will also feel at ease when financial institutions and consumers are protected from bad debts in a sustainably developing and transparent market. In this paper, we give an overview of credit report/credit score models in the United States. Base on that we draft a proposal to build a national credit database system in Vietnam using the new 12-digit identification numbers. We also propose how to use credit ratings more efficiently so that more small and medium enterprises can obtain credit from financial institutions.

\section{References}

[1] Small firms in Vietnam lack access to bank credit, The Voice of Vietnam (2016). Website: http://english.vov.vn/economy/small-firms-invietnam-lack-access-to-bank-credit-337549.vov

[2] NA deputies seek greater clarity around new identification cards, Vietnamnet (2014). Website: $\mathrm{http} / /$ english.vietnamnet.vn/fms/government/100 806/na-deputies-seek-greater-clarity-around-newidentification-cards.html

[3] The Consumer Financial Protection Bureau, USA. Website: http://www.consumerfinance.gov/

[4] Experian. Website: http://www.experian.com/

[5] Equifax. Website: http://www.equifax.com

[6] Fair Isaac Corporation. Website: http://www.myfico.com/

[7] Doctor of Credit. Website: http://www.doctorofcredit.com/

[8] The National Credit Information Centre of Vietnam. Website: http://pcb.vn/en/

[9] Vietnam Credit Information Joint Stock Company. Website: http://cic.org.vn/ 